\title{
An experimental study on the effects of nutrient enrichment on organic carbon persistence in the western Pacific oligotrophic gyre
}

\author{
J. Liu ${ }^{1,2}$, N. Jiao ${ }^{1,2}$, and K. Tang ${ }^{1,2}$ \\ ${ }^{1}$ State Key Laboratory of Marine Environmental Sciences, Xiamen University, Xiamen 361005, China \\ ${ }^{2}$ Institute of Marine Microbes and Ecospheres, Xiamen University, Xiamen 361005, China \\ Correspondence to: N. Jiao (jiao@xmu.edu.cn)
}

Received: 31 January 2014 - Published in Biogeosciences Discuss.: 21 February 2014

Revised: 18 August 2014 - Accepted: 20 August 2014 - Published: 23 September 2014

\begin{abstract}
Carbon sequestration in the ocean is of great concern with respect to the mitigation of global warming. How to hold the fixed organic carbon in the presence of tremendous numbers of heterotrophic microorganisms in marine environments is the central issue. We previously hypothesized that excessive nutrients would ultimately decrease the storage of organic carbon in marine environments. To test this, a series of in situ nutrient enrichment incubation experiments were conducted at a site $\left(17.59^{\circ} \mathrm{N}, 127.00^{\circ} \mathrm{E}\right)$ within the western Pacific oligotrophic gyre. Five treatments were employed: glucose (Glu), algal exudation organic material $(\mathrm{EOM})$, nitrate $(\mathrm{N})$ and phosphate $(\mathrm{P}), \mathrm{N}$ and $\mathrm{P}$ in combination with glucose and a control with no added nutrients. The results showed that the dissolved organic carbon consumption rates and bacterial community specific growth rates were enhanced by inorganic nutrient enrichment treatments during the initial $48 \mathrm{~h}$ incubation. At the end of 14 days of incubation, about one-third (average $3.3 \mu \mathrm{mol} \mathrm{C} \mathrm{kg}^{-1}$ ) more organic carbon was respired in the glucose-enriched incubation with the addition of inorganic nutrients compared to that without. In contrast, when nutrients were limiting, glucose could not be efficiently used by the bacteria and thus it remained in the environment. These results suggest that repletion of inorganic nutrients could facilitate microbial consumption of organic carbon and thus has a significant impact on carbon cycling in the environment.
\end{abstract}

\section{Introduction}

Dissolved organic carbon (DOC) in the ocean, as one of the largest carbon reservoirs on the earth, is comparable to the entire atmospheric $\mathrm{CO}_{2}$ reservoir $(\sim 750 \mathrm{Gt}$; Hedges, 1992; Ogawa and Tanoue, 2003) and plays an important role in global carbon cycling and climate change. A great deal of research effort has been directed to the processes and mechanisms involved in DOC dynamics, including production, consumption, and long-term storage of DOC. Recalcitrant dissolved organic carbon (RDOC), which comprises the largest portion of the bulk ocean DOC reservoir, can persist for thousands of years in the water column (Blitz, 1992), constituting significant carbon sequestration in the ocean. Therefore, how RDOC is produced and stored is essential for understanding DOC dynamics and has been one of the hot topics among biogeochemists for more than a decade (Søndergaard et al., 2000; Kragh and Søndergaard, 2004; Eichinger et al., 2009; Kragh and Søndergaard, 2009). Recently, the role of microbes in formation of RDOC is proposed as the microbial carbon pump (MCP) (Jiao et al., 2010a). One of the MCP rationales lies in the constraints of microbial DOC consumption (Jiao et al., 2011).

Although great progress has been made in microbial growth and production under different environmental conditions in the past decades (e.g., Goldman, 1987; Zweifel et al., 1993; Carlson and Ducklow, 1996; Cherrier et al., 1996; Cotner et al., 1997; Kirchman and Rich, 1997; Rivkin and Anderson, 1997; Thingstad et al., 1998; Carlson et al., 2002; Caron et al., 2000; Sala et al., 2002; Pinhassi et al., 2006), controversy remains to be addressed regarding remaining DOC versus nutrient availability. It is generally considered that enrichment of inorganic nutrients can result in the enhancement of primary production (Falkowski et al., 1998), subsequently leading to enhanced DOC release into the environment (Carlson et al., 1994; Biddanda and Benner, 
1997; Hansell and Carlson, 1998). However, such DOC is highly available to heterotrophic consumption, and thus cannot build up high concentrations (Roson et al., 1999; Chen et al., 2007). On the other hand, the so-called "malfunction of the microbial loop" effect could cause degradable DOC accumulation in productive surface water (Thingstad et al., 1997). Obviously carbon storage in the environment is not necessarily the result of nutrient enrichment. In fact, eutrophication waters such as estuaries are often sources rather than sinks of $\mathrm{CO}_{2}$ (Laruelle et al., 2010; Yuan et al., 2010). Therefore, we proposed that excessive inorganic nutrients would play against organic carbon storage in the marine environment (Jiao et al., 2010b). To test this point, nutrient enrichment experiments should be carried out in oligotrophic waters rather than coastal waters where sources of nutrients and DOC were myriad (Coble et al., 1990; Cabaniss and Shuman, 1987). In the present study, we conducted a set of in situ microcosm experiments in the western Pacific gyre where the low background concentrations of nutrients (below detection limit) and DOC $\left(81.5 \mu \mathrm{mol} \mathrm{C} \mathrm{kg}^{-1}\right)$ allowed us to check the effects of nutrient enrichment on resistance of DOC to microbial consumption manifestly.

\section{Materials and methods}

\subsection{Experimental design and sampling}

Seawater was collected from a depth of $75 \mathrm{~m}$ in the western Pacific Ocean $\left(17.59^{\circ} \mathrm{N}, 127.00^{\circ} \mathrm{E}\right)$, using a rosette sampler with a conductivity-temperature-depth instrument on 27 November 2012. The experiment was carried out with 10 microcosms (polycarbonate bottles, 20L) which were preacid-washed and rinsed with sample water. The filter system was pre-cleaned with copious ultrapure water and seawater in turn to minimize carbon contamination. Each microcosm was filled with $20 \mathrm{~L}$ seawater pre-filtered through a $3 \mu \mathrm{m}$ filter. Treatments were amended with organic carbon sources and inorganic nutrients as described in Table 1. Each treatment was conducted in replicate. The microcosms were incubated at $28 \pm 0.5^{\circ} \mathrm{C}$ in darkness. Cultures were sampled at hour $0,3,6,12,24,36,48,96,168$ and 336, and water samples were stored at $-20^{\circ} \mathrm{C}$ until analysis.

\subsection{Algal culture and dissolved organic material extraction}

Axenic culture of Phaeodactylum tricornutum was incubated in $f / 2$ medium with artificial seawater under a photon flux of $112 \mu \mathrm{E} \mathrm{m}^{-2} \mathrm{~s}^{-1}$ and a $10 \mathrm{~h}$ light/14 h dark cycle, with a temperature of $20 \pm 0.5^{\circ} \mathrm{C}$. To separate the medium from any algal cells, the culture was filtered through a $3 \mu \mathrm{m}$ filter when the stationary growth phase was reached. The algal exudation organic material (EOM) was extracted from the medium using solid-phase extraction cartridges (PPL, $1 \mathrm{~g}$, Agilent, Bond Elut) following Dittmar et al. (2008). The al- gal filtrate was acidified with $\mathrm{HCl}$ (final $\mathrm{pH}=2$ ) prior to passing through the cartridges. Ultrapure water (also acidified to $\mathrm{pH}=2$ with $\mathrm{HCl}$ ) was then used to remove excess salt from the cartridges, which secures the identical nutrient background between the EOM treatment and control. The EOM was eluted with methanol into pre-combusted glass vials $(40 \mathrm{~mL})$ after the sorbent was dried with nitrogen gas. The EOM was stored at $-20^{\circ} \mathrm{C}$ until the evaporation of methanol by nitrogen gas had been achieved. Before being transferred to the microcosms, the EOM was re-dissolved in $10 \mathrm{~mL}$ ultrapure water. Phytoplankton-derived organic matter plays a key role in carbon cycling due to its bioavailability. However the dissolved fraction was relatively low, accounting for only about $5 \%$ of the total released organic carbon of Phaeodactylum tricornutum (Becker et al., 2014). Furthermore, it is noteworthy that solid-phase extraction does not concentrate all algae exudate molecule equally, and only about $3.5 \%$ of total algae exudate organic carbon was recovered finally in this study.

\subsection{Total DOC (TOC) analysis}

Total dissolved organic matter was measured using the hightemperature combustion method with a Shimadzu TOC-V CPH TOC analyzer. To avoid potential organic carbon contamination, a filtration procedure was not applied in sampling. Consequently, bacterial biomass carbon was not ruled out, but it contributes less than $1 \%$ of TOC (Carlson and Ducklow, 1996). The samples were collected in glass vials $(40 \mathrm{~mL})$ with glass pipettes. All the glass apparatuses employed in sampling were pre-acid cleaned and combusted $\left(500^{\circ} \mathrm{C}, 6 \mathrm{~h}\right)$. Water samples were then acidified to $\mathrm{pH}=2$ with $\mathrm{H}_{3} \mathrm{PO}_{4}$ and stored at $-20^{\circ} \mathrm{C}$ until analysis. TOC measurement was based on Callahan et al. (2004). Culture samples were taken at hour $0,3,6,12,24,36,48,96,168$ and 336.

In this study, bacteria were considered as particulate organic carbon (POC) in the microcosm culture. POC concentration was estimated from bacterial abundance (BA) and the bacterial carbon conversion factor (CCF), which was assumed to be $20 \mathrm{fg} \mathrm{C} \mathrm{cell}^{-1}$ based on the natural planktonic assemblage (Lee and Fuhrman, 1987). The POC concentration could then be calculated using the following equation:

$\mathrm{POC}$ concentration $=\mathrm{BA} \times \mathrm{CCF}$.

DOC was defined as the TOC which did not include POC (the bacterial biomass carbon). Therefore, DOC concentration was calculated as

DOC concentration $=\mathrm{TOC}$ concentration $-\mathrm{POC}$ concentration.

In theory, the organic carbon decrease in the incubation system was the overall consequence of bacterial biomass carbon 
Table 1. Initial organic carbon and inorganic nutrient enrichment treatments in the experiments.

\begin{tabular}{|c|c|c|c|c|}
\hline \multirow[b]{2}{*}{ Treatments } & \multicolumn{2}{|c|}{ Carbon amendment } & \multicolumn{2}{|c|}{ Inorganic nutrient amendment } \\
\hline & $\begin{array}{c}\text { Glucose } \\
\left(\mu \mathrm{mol} \mathrm{C} \mathrm{kg}{ }^{-1}\right)\end{array}$ & $\begin{array}{c}\text { EOM } \\
\left(\mu \mathrm{mol} \mathrm{C} \mathrm{kg}^{-1}\right)\end{array}$ & $\begin{array}{l}\text { Inorganic nitrogen } \\
\left(\mu \mathrm{mol} \mathrm{Ng}^{-1}\right)\end{array}$ & $\begin{array}{l}\text { Inorganic phosphate } \\
\quad\left(\mu \mathrm{mol} \mathrm{Pg}^{-1}\right)\end{array}$ \\
\hline $\mathrm{Glu}+\mathrm{N}+\mathrm{P}$ & 7.9 & non & 1.53 & 0.11 \\
\hline Glu & 7.0 & non & nd & nd \\
\hline EOM & non & 7.0 & nd & nd \\
\hline $\mathrm{N}+\mathrm{P}$ & non & non & 1.54 & 0.11 \\
\hline Control & non & non & nd & nd \\
\hline
\end{tabular}

"non" means no organic carbon enrichment, and the background TOC concentration was $81.5 \mu \mathrm{mol} \mathrm{kg}^{-1}$.

"nd" means below the detection limit.

(POC) increase and bacterial respiration consumption which is comparable to the observed net TOC reduction (Carlson et al., 1999). Therefore, the bacterial respiration rate was estimated as

bacterial respiration rate $=\Delta \mathrm{TOC}$ concentration $/ \Delta t$.

\subsection{BA analysis and specific growth rate}

The culture was sampled at hour $0,3,6,12,24,36,48,96$, 120, 144, 168 and 336. Samples were fixed with glutaraldehyde to a final concentration of $1 \%$ (Vaulot et al., 1989) and frozen in liquid nitrogen prior to storage at $-80^{\circ} \mathrm{C}$. Bacteria were stained with SYBR Green I (Marie et al., 1997) before using a flow cytometer (Becton Dickinson), and the autotrophs were run separately without being stained (Jiao et al., 2005).

Specific growth rate was measured from 0 to $48 \mathrm{~h}$ and from 120 to $168 \mathrm{~h}$ and calculated as follows:

specific growth rate $=\ln (\Delta \mathrm{BA}) / \Delta t$,

where $\triangle \mathrm{BA}$ represents the observed net change in BA.

\subsection{Analysis of dissolved inorganic nutrient concentration}

The concentrations of dissolved inorganic nutrients in the samples were measured using a Technicon AA3 AutoAnalyzer (Bran-Lube, $\mathrm{GmbH}$ ). The copper-cadmium reduction method was employed to determine the dissolved inorganic nitrogen (DIN, nitrate and nitrite) concentrations of each sample. The spectrophotometric method was employed to determine dissolved inorganic phosphorus (DIP) concentration (Knap et al., 1996). The detection limits for DIN and DIP were $0.1 \mu \mathrm{mol} \mathrm{kg}{ }^{-1}$ and $0.08 \mu \mathrm{mol} \mathrm{kg}{ }^{-1}$.

\section{Results and discussion}

\subsection{Dynamics of BA and growth rate}

In general, BA in all treatments showed a similar growth pattern transitioning through lag, logarithmic and station-

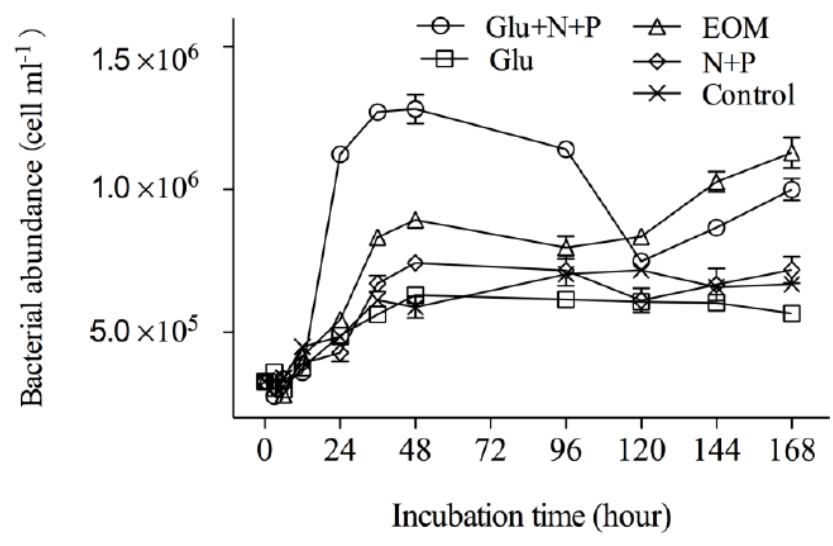

Figure 1. Variations of bacterial abundance during the incubation time course in various treatments. Error bars indicate the standard errors.

ary phases but with different levels of maximum abundance (Fig. 1). Compared to the control, the most pronounced differences were observed in the Glu $+\mathrm{N}+\mathrm{P}$ treatment, followed by the EOM and $\mathrm{N}+\mathrm{P}$ treatments. In contrast, the glucose (Glu) treatment did not show much difference from the control. The specific growth rates during $0-48 \mathrm{~h}$ of all the treatments, except for the Glu treatment, were significantly higher than that of the control (analysis of variance (ANOVA) test, $p<0.05$ ) (Table 2). In the Glu treatment the no/slight bacterial response to enrichment with Glu, a labile DOC source, seemed to be unreasonable, but such situations do exist in oligotrophic oceans as reported in the Sargasso Sea (Carlson et al., 1996). These results actually suggest a case of nutrient limiting rather than carbon limiting for the microbial community. In our study, the bacterial specific growth rate in $\mathrm{N}+\mathrm{P}$ treatments was significantly higher than that in the control (ANOVA test, $p<0.05$ ) (Table 2), and the same result was obtained for BA at $48 \mathrm{~h}$ (Fig. 1), indicating that inorganic nutrient addition could stimulate bacterial growth in the logarithmic phase. This was consistent with the results of Carlson et al. (2002) from the Sargasso Sea ( 2 days, 0.08 cell $\mathrm{L}^{-1} \mathrm{~d}^{-1}$ and 0.06 cell $\left.\mathrm{L}^{-1} \mathrm{~d}^{-1}\right)$. When 
Table 2. The DOC consumption rate, bacterial community specific growth rate, bacterial abundance (BA) and bacterial respiration rate (BR) in the incubation experiments.

\begin{tabular}{lccccc}
\hline Treatments & $\begin{array}{c}\text { DOC } \\
\text { consumption } \\
\text { rate }(0-48 \mathrm{~h})\end{array}$ & $\begin{array}{c}\text { Specific growth rate }\left(\mathrm{h}^{-1}\right) \\
0-48 \mathrm{~h}\end{array}$ & $\begin{array}{c}\text { BA }(336 \mathrm{~h}) \\
\left(10^{5} \text { cell }\right. \\
\left.\mathrm{mL}^{-1}\right)\end{array}$ & $\begin{array}{c}\text { BR } \\
(\mu \mathrm{mol} \mathrm{C} \\
\left.\mathrm{kg}^{-1} \mathrm{~d}^{-1}\right)\end{array}$ \\
\hline Glu + N+P & $0.232 \pm 0.038$ & $0.022 \pm 0.0008$ & $0.005 \pm 0.0005$ & $12.82 \pm 0.51$ & $5.46 \pm 0.19$ \\
Glu & $0.141 \pm 0.021$ & $0.009 \pm 0.0002$ & - & $6.30 \pm 0.06$ & $3.45 \pm 0.58$ \\
EOM & $0.163 \pm 0.028$ & $0.015 \pm 0.0003$ & $0.006 \pm 0.0008$ & $8.94 \pm 0.26$ & $3.50 \pm 0.88$ \\
N + P & $0.170 \pm 0.022$ & $0.012 \pm 0.0005$ & - & $7.43 \pm 0.17$ & $4.03 \pm 0.27$ \\
Control & $0.134 \pm 0.024$ & $0.008 \pm 0.0003$ & - & $5.88 \pm 0.37$ & $3.46 \pm 0.46$ \\
\hline
\end{tabular}

The DOC consumption rate was estimated from the absolute value of the slope of the linear regression on all collected data of DOC concentration during $0-48 \mathrm{~h}$. The BR was estimated from the observed net TOC concentration reduction in the corresponding incubation time $(0-48 \mathrm{~h})$.

- Non-measurement during $120-168 \mathrm{~h}$ due to no obvious bacterial abundance enhancement.

Data were mean $\pm \mathrm{SE}$ (standard error).

Glu was with $\mathrm{N}+\mathrm{P}$, it made the most robust difference, and the $\mathrm{BA}$ reached $1.25 \times 10^{6}$ cells $\mathrm{mL}^{-1}$ at $48 \mathrm{~h}$, which was the highest value among all the treatments, with specific growth rates of 1.8 - to 2.5 -fold that of the $\mathrm{N}+\mathrm{P}$ treatments during the $0-48 \mathrm{~h}$ incubation (Fig. 1 and Table 2). These results demonstrated that even labile DOC such as Glu could not be used by microbes and would be left over in the environment if no essential nutrients were available. On the one hand, this meant that bacterial growth not only required organic carbon but also required inorganic nutrients; it may be possible for a labile DOC molecule to become semi-labile or instantly refractory to bacteria if nutrients are not available. The argument could be raised here as to whether inorganic nutrients are essential for bacteria. The results of EOM treatment (without supplementary inorganic nutrients) showed that the BA and specific growth rate were significantly higher than in the control and even other treatments (except for the Glu $+\mathrm{N}+\mathrm{P}$ treatment) during the $0-48$ hour period. Since EOM must contain organic nitrogen, phosphorus and other elements, it is possible to say that elemental balance is a key for bacterial growth and abundance. In the case where the labile organic matter (which contains diverse elements) is not enough, inorganic nutrients could be substituted to meet the bacterial demand for growth elements in the oligotrophic ocean.

\subsection{Dynamics of the inorganic nutrients}

Dissolved inorganic nutrient ( $\mathrm{N}$ and $\mathrm{P}$ ) concentrations in non-nutrient enrichment treatments (Glu, EOM and control treatments) were all below the detection limits (Fig. 2a and $\mathrm{b}$ ). For the nutrient ( $\mathrm{N}$ and $\mathrm{P}$ )-enriched treatments, the variation of nutrient concentrations during the incubation time course was different between the Glu $+\mathrm{N}+\mathrm{P}$ and $\mathrm{N}+\mathrm{P}$ treatments. In the $\mathrm{Glu}+\mathrm{N}+\mathrm{P}$ treatment, after a lag phase $(0-12 \mathrm{~h})$, the DIN decreased rapidly from 1.45 to $0.77 \mu \mathrm{mol} \mathrm{N} \mathrm{kg}{ }^{-1}$ during the $12-48 \mathrm{~h}$ period, and then maintained a low level (around $0.66 \mu \mathrm{mol} \mathrm{N} \mathrm{kg}^{-1}$ ) dur- ing the $48-336 \mathrm{~h}$ period (Fig. 2a). In contrast, the DIN in the $\mathrm{N}+\mathrm{P}$ treatment showed a prolonged gradual reduction over the $0-336 \mathrm{~h}$ incubation time course, decreasing from 1.54 to $1.13 \mu \mathrm{mol} \mathrm{N} \mathrm{kg}{ }^{-1}$ in total (Fig. 2a). Moreover, in the $\mathrm{Glu}+\mathrm{N}+\mathrm{P}$ treatment, the DIP was rapidly consumed during the first $6 \mathrm{~h}\left(0.11\right.$ to $\left.0.09 \mu \mathrm{mol} \mathrm{P} \mathrm{kg}{ }^{-1}\right)$ and reduced to below the detection limit within $12 \mathrm{~h}$ (Fig. 2b). In the $\mathrm{N}+\mathrm{P}$ treatment, however, DIP decreased slowly from 0.11 to $0.09 \mu \mathrm{mol} \mathrm{P} \mathrm{kg}^{-1}$, during $0-72 \mathrm{~h}$, and then suddenly dropped to below the detection limit after $96 \mathrm{~h}$ (Fig. 2b). The difference in dynamics of the nutrients between the $\mathrm{Glu}+\mathrm{N}+\mathrm{P}$ and $\mathrm{N}+\mathrm{P}$ treatments suggested that inorganic nutrient uptake could be significantly enhanced by labile organic carbon (e.g., Glu) enrichment.

\subsection{Dynamics of TOC and DOC concentrations}

TOC concentrations in all treatments, including the control, were monitored during the entire incubation time course ( $336 \mathrm{~h})$ to check the differences in consumption of organic carbon between the treatments. Generally, TOC concentrations decreased rapidly in the initial $48 \mathrm{~h}$ and then became relatively stable during the later hours (48-336h) at different levels in different treatments (Fig. 3). The fraction of DOC consumed in the first $48 \mathrm{~h}$ accounted for 8 to $13 \%$ of the initial bulk DOC varying with different treatments (Table 2). The Glu $+\mathrm{N}+\mathrm{P}$ treatment showed the highest DOC consumption rate $\left(0.232 \mu \mathrm{mol} \mathrm{C} \mathrm{kg}^{-1} \mathrm{~h}^{-1}\right)$ among all the treatments, most likely due to the combined effects of nutrient and organic carbon enrichment. DOC consumption rates in the $\mathrm{N}+\mathrm{P}$ treatment ranked second highest $\left(0.170 \mu \mathrm{mol} \mathrm{C} \mathrm{kg}{ }^{-1} \mathrm{~h}^{-1}\right)$, indicating that nutrient enrichment did stimulate the uptake of organic carbon as previously hypothesized (Jiao et al., 2010b). The DOC consumption rate in the EOM treatment $\left(0.163 \mu \mathrm{mol} \mathrm{C} \mathrm{kg}^{-1} \mathrm{~h}^{-1}\right)$ was similar to the $\mathrm{N}+\mathrm{P}$ treatment. However, the mechanism behind DOC utilization could be quite different. EOM provided not only carbon but also the other elements including 

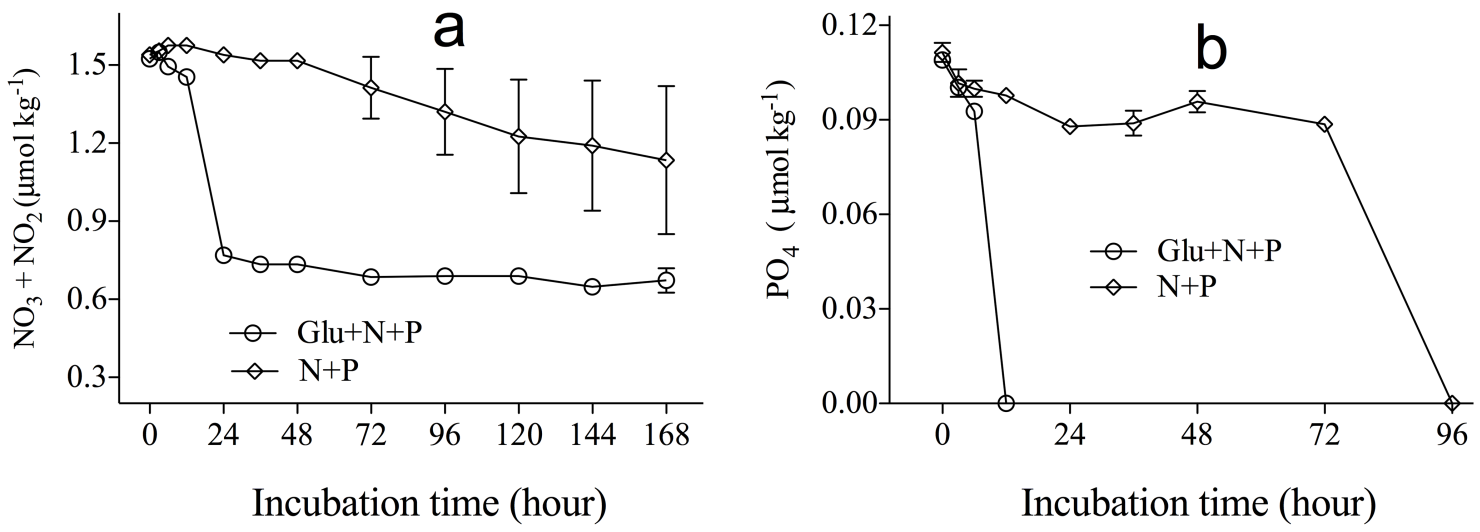

Figure 2. Variations of dissolved inorganic nitrogen and phosphate concentrations during the incubation time course of the nutrient-enriched treatments. (Non-inorganic-nutrient-enrichment treatments are not shown since they were below the detection limits.) Value "0" in (b) means below the detection limit. Error bars indicate standard errors.

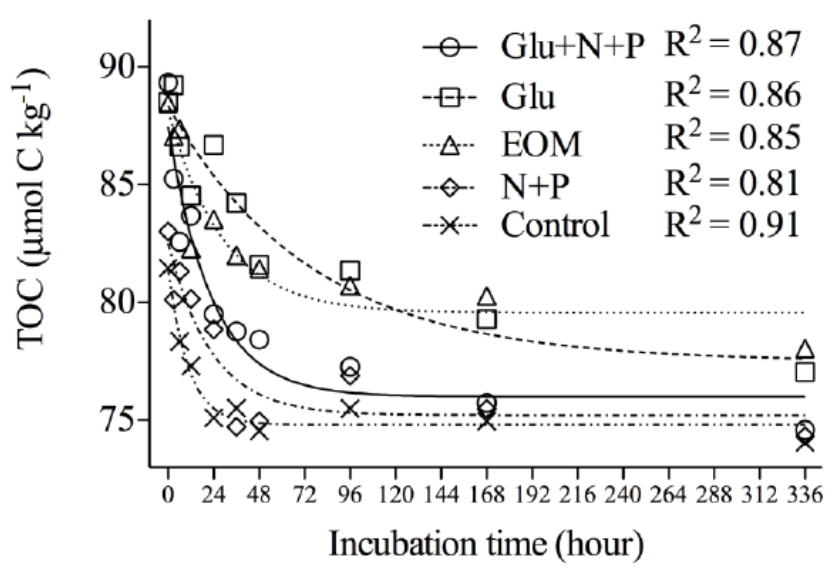

Figure 3. Variations of TOC concentrations during the incubation time course of various treatments. The non-linear regression lines were obtained from the corresponding TOC concentration observations during the entire incubation. Symbols shown in the figure are the mean values of TOC concentrations at each sampling point.

$\mathrm{N}$ and $\mathrm{P}$ necessary for the bacterial demand. In contrast if only organic carbon had been supplied, like the case of Glu treatment, bacteria may not have been able to use much carbon $\left(0.141 \mu \mathrm{mol} \mathrm{C} \mathrm{kg}^{-1} \mathrm{~h}^{-1}\right.$, similar to the control, $0.134 \mu \mathrm{mol} \mathrm{C} \mathrm{kg}^{-1} \mathrm{~h}^{-1}$ ) due to the elemental limitation of $\mathrm{N}$ and $\mathrm{P}$ (Table 2). A number of studies have shown that algal excretions are a complex mixture of organic material, comprised largely of polysaccharides, small nitrogenous compounds, lipids, vitamins, etc. (Goldman et al., 1992; Myklestad et al., 1989; Mague et al., 1980). Therefore EOM could have been more efficient than Glu alone for bacterial growth in oligotrophic waters. It is noteworthy that while the DOC consumption rates in the $\mathrm{EOM}$ and $\mathrm{N}+\mathrm{P}$ treatments were similar, the bacterial respiration rates in the two treatments were quite different (higher in the latter; Table 2), which was likely due to the fact that more energy is needed for the syn- thesis of biomass (protein etc.) in the case of $\mathrm{N}+\mathrm{P}$ treatment. Among all the treatments, the highest bacterial respiration rates were observed in the Glu $+\mathrm{N}+\mathrm{P}$ treatment, contrasting to the lowest in the Glu treatment, which was actually the same as the control. Taking together the DOC consumption and bacterial respiration, it was clear that inorganic nutrients stimulated bacterial respiration and led to more carbon consumption in the same organic carbon availability scenario.

As the less organic carbon used by microbes, the more organic carbon would be left in the environment. Compared to the Glu treatment, more than $3.3 \mu \mathrm{mol} \mathrm{C} \mathrm{kg}^{-1} \mathrm{TOC}$ on average was consumed in the $\mathrm{Glu}+\mathrm{N}+\mathrm{P}$ treatment after $336 \mathrm{~h}$ incubation. This suggested that inorganic nutrient enrichment was not beneficial for organic carbon persistence, and that the bio-availability and lability of an organic carbon compound could be situation-specific. Therefore, the term RDOC could be refined as the deep ocean RDOC (which has generally been used by chemists), and situational RDOC (Jiao et al., 2014), which means that it can hold recalcitrance under certain conditions but may become bioavailable when conditions change (such as nutrient enrichment). Such situations actually exist in the oceans. For example, the highest DOC concentration among the oceanic waters of the world is located in the Southern Ocean gyre (Hansell et al., 2009), where nutrients are limiting, and stratification is strong.

Before the present study, there were many studies on the limiting factors of bacterial growth and/or bacterial production (Supplement Table S1), and the results differ among different experiments. In some cases enrichment of inorganic nutrient ( $\mathrm{N}$ and/or $\mathrm{P}$ ) stimulated bacterial growth and/or bacterial production (Rivkin and Anderson, 1997; Cotner et al., 1997; Thingstad et al., 1998; Caron et al., 2000; Sala et al., 2002; Pinhassi et al., 2006), while in other cases bacterial growth and/or production were proven to be limited by organic carbon (Kirchman and Rich, 1997; Rivkin and Anderson, 1997; Pinhassi et al., 2006). Meanwhile co-limitation 
by organic carbon and inorganic nutrients was also reported (Pomeroy et al., 1995; Donachie et al., 2001; Hoikkala et al., 2009). These studies mainly focused on the microbial abundance/production/respiration rather than organic carbon left over in the environment, although some of them have discussed DOC dynamics. There were a few studies that followed DOC dynamics during the incubations, and found that organic carbon rather than nutrients is the limiting factor for bacterial activities (Cherrier et al., 1996; Carlson et al., 1996; Carlson et al., 2002).

In contrast, the direct coupling between DOC dynamics and bacterial activities in the present study showed that inorganic nutrients rather than organic carbon were the limiting factor in the Pacific oligotrophic gyre. Meanwhile our study showed the negative effects of nutrient enrichment on DOC persistence in the environment.

\section{Conclusions and prospects}

It is generally known that enrichment of inorganic nutrients would increase carbon fixation, but this is not necessarily true for carbon preservation in the environment. Our in situ incubation experiments in the western Pacific gyre showed that nitrate and phosphate addition stimulated organic carbon consumption and bacterial respiration and ultimately resulted in reduction of organic carbon remained in the environment. In contrast, if nitrogen and phosphorus are limiting (oligotrophic case), even if provided with labile carbon molecules such as glucose, bacteria may not take it up efficiently. On the other hand, natural labile organic matter such as EOM, containing multiple elements, would fuel bacteria efficiently. Taken together, these recognitions are useful for interpreting some paradoxes such as why eutrophic estuarine waters are often sources rather than sinks of $\mathrm{CO}_{2}$. That is, although nutrients are rich in estuarine waters, autotrophs are limited by light availability, whereas heterotrophic microbes could be simulated by both labile DOC such as EOM and deplete nutrients. As a result, consumption of environmental organic carbon (including some of the river discharged) could exceed primary production resulting in outgassing rather than uptake of $\mathrm{CO}_{2}$ in the system. These recognitions can be referred to for coastal water management regarding ecological health and carbon sequestration. Further studies are desired to explore the concentration ranges, optimum elemental ratios of nutrients which are most favorable for shifting the carbon cycle equilibrium towards organic carbon storage in a variety of marine environments.

The Supplement related to this article is available online at doi:10.5194/bg-11-5115-2014-supplement.
Acknowledgements. We thank the crew of the R/V Kexue - 1 for the smooth sampling. We also thank John Hodgkiss for the assistance with English. This work was supported by National Key Basic Research Program of China (grant no. 2013CB955700) and the SOA Project (GASI-03-01-02-05, 201105021).

Edited by: H. Thomas

\section{References}

Becker, J. W., Berube, P. M., Follett, C. L., Waterbury, J. B., Chisholm, S. W., Delong, E. F., and Repeta, D. J.: Closely related phytoplankton species produce similar suites of dissolved organic matter, Front. Microbiol., 5, 111, doi:10.3389/fmicb.2014.00111, 2014.

Biddanda, B. and Benner, R.: Carbon, nitrogen, and carbohydrate fluxes during the production of particulate and dissolved organic matter by marine phytoplankton, Limnol. Oceanogr., 42, 506518, 1997.

Blitz, L.: ${ }^{14} \mathrm{C}$ activity of dissolved organic carbon fractions in the north-central Pacific and Sargasso Sea, Nature, 357, 667-670, 1992.

Cabaniss, S. E. and Shuman, M. S.: Synchronous fluorescence spectra of natural waters: tracing sources of dissolved organic matter, Mar. Chem., 21, 37-50, 1987.

Callahan, J., Dai, M., Chen, R. F., Li, X., Lu, Z., and Huang, W.: Distribution of dissolved organic matter in the Pearl River Estuary, China, Mar. Chem., 89, 211-224, 2004.

Carlson, C. A. and Ducklow, H. W.: Growth of bacterioplankton and consumption of dissolved organic carbon in the Sargasso Sea, Aquat. Microb. Ecol., 10, 69-85, 1996.

Carlson, C. A., Ducklow, H. W., and Michaels, A. F.: Annual flux of dissolved organic carbon from the euphotic zone in the northwestern Sargasso Sea, Nature, 371, 405-408, 1994.

Carlson, C. A., Bates, N. R., Ducklowz, H. W., and Hansell, D. A.: Estimation of bacterial respiration and growth, Aquat. Microb. Ecol., 19, 229-244, 1999.

Carlson, C. A., Giovannoni, S. J., Hansell, D. A., Goldberg, S. J., Parsons, R., Otero, M. P., Vergin, K., Caron, D. A., Lim, E. L., Sanders, R. W., Dennett, M. R., and Berninger, U. G.: Responses of bacterioplankton and phytoplankton to organic carbon and inorganic nutrient additions in contrasting oceanic ecosystems, Aquat. Microb. Ecol., 22, 175-184, 2000.

Chen, F. Z., Cai, W. J., Benitez-Nelson, C., and Wang, Y. C.: Sea surface $\mathrm{pCO}_{2}$-SST relationships across a cold-core cyclonic eddy: Implications for understanding regional variability and air-sea gas exchange, Geophys. Res. Lett., 34, L10603, doi:10.1029/2006GL028058, 2007.

Cherrier, J., Bauer, J., and Druffel, E.: Utilization and turnover of labile dissolved organic matter by bacterial heterotrophs in eastern North Pacific surface waters, Mar. Ecol.-Prog. Ser., 139, 267279, 1996.

Coble, P. G., Green, S. A., Blough, N. V., and Gagosian, R. B.: Characterization of dissolved organic matter in the Black Sea by fluorescence spectroscopy, Nature, 348, 432-435, 1990.

Cotner, J., Ammerman, J., Peele, E., and Bentzen, E.: Phosphoruslimited bacterioplankton growth in the Sargasso Sea, Aquat. Microb. Ecol., 13, 141-149, 1997. 
Dittmar, T., Koch, B., Hertkorn, N., and Kattner, G.: A simple and efficient method for the solid-phase extraction of dissolved organic matter (SPE-DOM) from seawater, Limnol. Oceanogr.Methods, 6, 230-235, 2008.

Donachie, S. P., Christian, J. R., and Karl, D. M.: Nutrient regulation of bacterial production and ectoenzyme activities in the subtropical North Pacific Ocean, Deep-Sea Res. Pt. II., 48, 1719 1732, 2001

Eichinger, M., Kooijman, S., Sempere, R., Lefèvre, D., Gregori, G., Charrière, B., and Poggiale, J. C.: Consumption and release of dissolved organic carbon by marine bacteria in a pulsed-substrate environment: from experiments to modelling, Aquat. Microb. Ecol., 56, 41-54, 2009.

Falkowski, P. G., Barber, R. T., and Smetacek, V.: Biogeochemical controls and feedbacks on ocean primary production, Science, 281, 200-206, 1998.

Goldman, J. C., Caron, D. A., and Dennett, M. R.: Regulation of gross growth efficiency and ammonium regeneration in bacteria by substrate C:N ratio, Limnol. Oceanogr., 32, 1239-1252, 1987.

Goldman, J. C., Hansell, D. A., and Dennett, M. R.: Chemical characterization of three large oceanic diatoms: potential impact on water column chemistry, Mar. Ecol.-Prog. Ser., 88, 257-270, doi:10.3354/meps088257, 1992.

Hansell, D. A. and Carlson, C. A.: Net community production of dissolved organic carbon, Global Biogeochem. Cy., 12, 443-453, 1998.

Hansell, D. A., Carlson, C. A., Repeta, D. J., and Schlitzer, R.: Dissolved organic matter in the ocean: A controversy stimulates new insights, Oceanogr., 22, 52-61, 2009.

Hedges, J. I.: Global biogeochemical cycles: progress and problems, Mar. Chem., 39, 67-93, 1992.

Hoikkala, L., Aarnos, H., and Lignell, R.: Changes in nutrient and carbon availability and temperature as factors controlling bacterial growth in the northern Baltic Sea, Estuar. Coast., 32, 720$733,2009$.

Jiao, N., Yang, Y., Hong, N., Ma, Y., Harada, S., Koshikawa, H., and Watanabe, M.: Dynamics of autotrophic picoplankton and heterotrophic bacteria in the East China Sea, Cont. Shelf Res., 25, 1265-1279, 2005.

Jiao, N., Herndl, G. J., Hansell, D. A., Benner, R., Kattner, G., Wilhelm, S. W., Kirchman, D. L., Weinbauer, M. G., Luo, T., Chen, F., and Azam, F.: Microbial production of recalcitrant dissolved organic matter: long-term carbon storage in the global ocean, Nature Rev. Microbiol., 8, 593-599, doi:10.1038/nrmicro2386, 2010a.

Jiao, N., Tang, K., Cai, H., and Mao, Y.: Increasing the microbial carbon sink in the sea by reducing chemical fertilization on the land, Nature Rev. Microbiol., 9, 75-75, 2010b.

Jiao, N. and Azam, F.: Microbial carbon pump and its significance for carbon sequestration in the ocean, in: Microbial Carbon Pump in the Ocean, edited by: Jiao, N., Azam, F., and Sanders, S., Science/AAAS, Washington, DC, 43-45, 2011.

Jiao, N., Robinson, C., Azam, F., Thomas, H., Baltar, F., Dang, H., Hardman-Mountford, N. J., Johnson, M., Kirchman, D. L., Koch, B. P., Legendre, L., Li, C., Liu, J., Luo, T., Luo, Y.-W., Mitra, A., Romanou, A., Tang, K., Wang, X., Zhang, C., and Zhang, R.: Mechanisms of microbial carbon sequestration in the ocean -future research directions, Biogeosciences Discuss., 11, 79317990, doi:10.5194/bgd-11-7931-2014, 2014.
Kirchman, D. L., and Rich, J. H.: Regulation of Bacterial Growth Rates by Dissolved Organic Carbon and Temperature in the Equatorial Pacific Ocean, Microb. Ecol., 33, 11-20, 1997.

Knap, A., Michaels, A., Close, A., Ducklow, H., and Dickson, A.: Protocols for the joint global ocean flux study (JGOFS) core measurements, JGOFS Report No. 19, Reprint of the IOC Manuals and Guides No. 29, UNESCO, 1996.

Kragh, T. and Søndergaard, M.: Production and bioavailability of autochthonous dissolved organic carbon: effects of mesozooplankton, Aquat. Microb. Ecol., 36, 61-72, 2004

Kragh, T. and Søndergaard, M.: Production and decomposition of new DOC by marine plankton communities: carbohydrates, refractory components and nutrient limitation, Biogeochemistry, 96, 177-187, 2009.

Laruelle, G. G., Dürr, H. H., Slomp, C. P., and Borges, A. $\mathrm{V}$.: Evaluation of sinks and sources of $\mathrm{CO}_{2}$ in the global coastal ocean using a spatially-explicit typology of estuaries and continental shelves, Geophys. Res. Lett., 37, L15607, doi:10.1029/2010GL043691, 2010.

Lee, S. and Fuhrman, J. A.: Relationships between biovolume and biomass of naturally derived marine bacterioplankton, Appl. Environ. Microb., 53, 1298-1303, 1987.

Mague, T., Friberg, E., Hughes, D., and Morris, I.: Extracellular release of carbon by marine phytoplankton; a physiological approach, Limnol. Oceanogr., 25, 262-279, 1980.

Marie, D., Partensky, F., Jacquet, S., and Vaulot, D.: Enumeration and cell cycle analysis of natural populations of marine picoplankton by flow cytometry using the nucleic acid stain SYBR Green I, Appl. Environ. Microb., 63, 186-193, 1997.

Myklestad, S., Holm-Hansen, O., Vårum, K. M., and Volcani, B. E.: Rate of release of extracellular amino acids and carbohydrates from the marine diatom Chaetoceros affinis, J. Plankton Res., 11, 763-773, 1989.

Ogawa, H. and Tanoue, E.: Dissolved organic matter in oceanic waters, J. Oceanogr., 59, 129-147, 2003.

Pinhassi, J., Gomez-Consarnau, L., Alonso-Saez, L., Sala, M. M., Vidal, M., Pedros-Alio, C., and Gasol, J. M.: Seasonal changes in bacterioplankton nutrient limitation and their effects on bacterial community composition in the NW Mediterranean Sea, Aquat Microb. Ecol., 44, 241-252, doi:10.3354/Ame044241, 2006.

Pomeroy, L. R., Sheldon, J. E., Sheldon, W. M., and Peters, F.: Limits to Growth and Respiration of Bacterioplankton in the Gulf-of-Mexico, Mar. Ecol.-Prog. Ser., 117, 259-268, doi:10.3354/Meps117259, 1995.

Rivkin, R. B. and Anderson, M. R.: Inorganic nutrient limitation of oceanic bacterioplankton, Limnol. Oceanogr., 42, 730-740, 1997.

Roson, G., Alvarez-Salgado, X. A., and Perez, F. F.: Carbon cycling in a large coastal embayment, affected by wind-driven upwelling: short-time scale variability and spatial differences, Mar. Ecol.Prog. Ser., 176, 215-230, doi:10.3354/Meps176215, 1999.

Sala, M. M., Peters, F., Gasol, J. M., Pedrós-Alió, C., Marrasé, C. and Vaqué, D.: Seasonal and spatial variations in the nutrient limitation of bacterioplankton growth in the northwestern Mediterranean, Aquat. Microb. Ecol., 27, 47-56, 2002.

Søndergaard, M., Borch, N. H., and Riemann, B.: Dynamics of biodegradable DOC produced by freshwater plankton communities, Aquat. Microb. Ecol., 23, 73-83, 2000. 
Thingstad, T. F., Hagström, A., and Rassoulzadegan, F.: Accumulation of degradable DOC in surface waters: Is it caused by a malfunctioning microbial loop?, Limnol. Oceanogr., 42, 398-404, 1997.

Thingstad, T. F., Zweifel, U. L., and Rassoulzadegan, F.: P limitation of heterotrophic bacteria and phytoplankton in the northwest Mediterranean, Limnol. Oceanogr., 43, 88-94, 1998.

Vaulot, D., Courties, C., and Partensky, F.: A simple method to preserve oceanic phytoplankton for flow cytometric analyses, $\mathrm{Cy}-$ tometry, 10, 629-635, 1989.
Yuan, X., Yin, K., Harrison, P. J., Cai, W.-J., He, L., and Xu, J.: Bacterial production and respiration in subtropical Hong Kong waters: influence of the Pearl River discharge and sewage effluent, Aquat. Microb. Ecol., 58, 167-179, 2010.

Zweifel, U. L.: Factors controlling accumulation of labile dissolved organic carbon in the Gulf of Riga, Estuar. Coast. Shelf S., 48, 357-370, doi:10.1006/ecss.1998.0428, 1999.

Zweifel, U. L., Norrman, B., and Hagstrom, A.: Consumption of dissolved organic carbon by marine bacteria and demand for inorganic nutrients, Mar. Ecol.-Prog. Ser., 101, 23-23, 1993. 